\title{
Effectiveness of Traditional KSM Dressing and TJ Honey on Healing Acute Wounds in Rats
}

\section{Suriadi $S^{*}$}

Department of Medicine, School of Nursing, Institute of Nursing Muhammadiyah Pontianak, University of Tanjungpura, Kalimantan Barat 78123, Indonesia

*Corresponding author: Suriadi S, Department of Medicine, School of Nursing, Institute of Nursing Muhammadiyah Pontianak, University of Tanjungpura, Kalimantan Barat 78123, Indonesia, Tel: +6281219499500; E-mail: suriadif@yahoo.com.au

Received date: October 10, 2019; Accepted date: October 24, 2019; Published date: October 31, 2019

Citation: Suriadi S (2019) Effectiveness of Traditional KSM Dressing and TJ Honey on Healing Acute Wounds in Rats. Herb Med Vol.5 No.2:7.

Copyright: (c) 2019 Suriadi S. This is an open-access article distributed under the terms of the Creative Commons Attribution License, which permits unrestricted use, distribution, and reproduction in any medium, provided the original author and source are credited.

\begin{abstract}
This animal study aimed to evaluate the effectiveness of the duration of acute wound healing in three groups using traditional dressings as controls namely KSM (Kurma Sama Madu), TJ (Tresno Joyo) honey and NS (Normal Saline). This study employed a quasi-experimental design that was divided into three groups: the first group used KSM dressing, the second group used TJ honey and the third (control) group used normal saline. This study's results demonstrate that traditional KSM dressing presents acceleration in the healing of acute wounds in animals. The statistical test revealed that KSM dressing significantly differs from normal saline ( $p$ value $<0.05$ ) although not from TJ honey, while TJ honey does not significantly differ from normal saline ( $p$ value $>0.05$ ). This study reports that KSM dressing and TJ honey are effective in accelerating the wound-healing process of acute wounds in animals.
\end{abstract}

Keywords: Acute wound; KSM dressing; TJ honey; Normal saline

\section{Introduction}

\section{Honey}

Studies of honey have been demonstrated in various reports as possessing strong wound-healing effects. Honey is produced from various sources of flora and its antibacterial activities vary according to its origin and processing. These various sources of flora affect the quality of honey's composition and its effect on tissue repair [1]. In Indonesia, honey dressing has been composed with various types of available honey and has been applied in clinical settings to treat both acute and chronic wounds. In Indonesia, studies have compared Indonesian forest honey and manuka honey, reporting that the former is more effective than the latter [2]. Honey has been widely employed in clinical settings such as in topical therapy to treat infections and skin lesions [3]. Honey has positive healing effects in that it reduces inflammation, the microbial burden (bioburden) and the decay of necrotic tissue which expands and enhances the angiogenesis, granulation, epithelialization of necrotic tissue, debrides and reduces odors [3-5]. An additional advantage of honey is its ability to reduce edema and pain due to its high level of osmolarity and its antibacterial properties, latter of which it produce enzymatically produced hydrogen peroxide at very low but in continuous levels, thereby causing cell stimulation and eliminating odors in wounds $[1,6,7]$. Both honey from the forest and honey that is brand are found in Indonesia. One type of honey that is consumed for traditional medicine is trigona honey, which is often used in Indonesia as a traditional medicine. It has been reported that honey is very effective at killing staphylococcus aureus and Escherichia coli, the former of which is known as the most common bacteria to contaminate wounds and inflict infections [8-11].

\section{KSM}

KSM dressing is a mixture of date and honey trigona extracts first of which performed in the chemical department of the Faculty of Natural Sciences and Mathematics at Tanjungpura University. KSM is a dressing that is mixed between the extracts of Ajwa dates and trigona honey in a 1:1 ratio. Dates are a common food consumed by Middle Eastern individuals as well as those living in Southeast Asian countries, such as Indonesia. In Indonesia, the public utilizes the syrup from dates to treat several infectious diseases for instance, compressing chronic wounds $[12,13]$. The literature study reports that dates can accelerate wound healing while other studies report that dates are very effective as an antiinflammatory and antimicrobial agent in that they accelerate cell proliferation and contribute to the healing of wounds [14-17]. In the results of a chemical analysis on dates, several contents, including minerals, flavonoids and high polyphenols can kill bacteria such as staphylococcus aureus and pseudomonas aeruginosa [14]. The extensive characterization of phenolic compounds and flavonoids constitutes an important source of anti-inflammatory compounds and is quite supportive in the wound-healing process [18]. Honey and 
dates are excellent sources of nutrition for bodily health as well as wound healing, the latter of which is a complex process that requires optimum wound care when considering an effective dressing product for the healing process that does not cause resistance to bacteria $[9,14,15]$. Wound care continues to evolve and wound care professionals are faced with several challenges. Due to the emergence of multiresistant organisms and the decline of new antibiotics wound care professionals have reviewed ancient healing methods using traditional and alternative methods of wound care [19]. Honey and dates have been evaluated and determined effective for wound healing, a second combination that promotes wound healing has not yet been evaluated and this study thus aims to evaluate the effectiveness of KSM dressing on the acceleration and/or duration of acute wound healing.

\section{Methods}

This study applied a quasi-experimental design with a control group. Fifteen rats were divided into three groups; group 1 used KSM honey, group 2 used TJ honey and group 3 used normal saline (NS). TJ honey is a brand in Indonesia and is sold freely in the market. Fifteen rats used in this study were separately confined in an animal laboratory room at the Institute of Nursing Muhammadiyah Pontianak (INMP) and were anaesthetized with an intraperitoneal injection of ketamine and xylazine $(0.5 \mathrm{ml})$. On day 0 , one full-thickness (5 $\mathrm{mm}$ ) circular wound including panniculus was made with a sterile disposable punch biopsy (Kai Industries Co. Ltd., Gifu, Japan) on one side of each rat's dorsum. In the experimental group, the wounds were treated with $0.1 \mathrm{ml} \mathrm{KSM}$ and $0.1 \mathrm{ml}$ commercial honey (TJ), while the control group was injected with $0.1 \mathrm{ml} \mathrm{NS}$. Treatments were applied using a $1 \mathrm{ml}$ syringe and all wounds received the same treatment. The wounds were covered with gauze as a secondary dressing for both to prevent runoff and absorb the leaking exudate from the wound surface. Gauze measuring $25 \mathrm{~mm} \times 25 \mathrm{~mm}$ was obtained from the sterilized gauze and plastered to glue the wound. Bandages were replaced every day the wounded area was wrapped twice with a sticky bandage such that the gauze applied directly into the wound could not be moved from its position. The wound-healing process was observed once a day from day 0 or first day until the wounds were closed. The experimental protocol was executed in accordance with the guidelines issued by the INMP for the care of animal use in laboratories and this study was approved by the INMP's research ethics committee (or institutional review board) under no.209/II.I.AU/Ket.Ethics/S-1/XII/2017. The study aimed to evaluate the effectiveness of the wound-healing duration via the three aforementioned dressing groups.

\section{Data analysis}

This study applied an ANOVA statistical analysis with a significant $p$ value $<0.05$ to analyze the three groups. The MedCalc statistical software (Acacialaan 22 B-8400 Ostend, Belgium) was employed to analyze the data of this study.

\section{Results}

This study aimed to evaluate a comparison of the woundhealing acceleration generated by the use of KSM dressing, TJ honey and NS as a control.

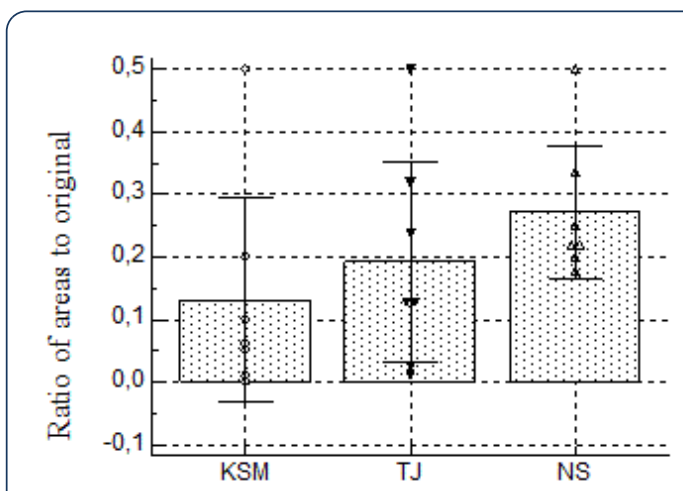

Note: Duration of each dressing's healing effect according to wound size. The values are expressed as Mean $\pm \mathrm{SE} ; \mathrm{n}=5$ per group.

Figure 1: The ratio of the wounds to initial areas on day 0.

Table 1: The mean values among the three groups.

\begin{tabular}{|l|l|l|l|}
\hline Variables & Mean & Std. Error & $\mathbf{9 5 \%} \mathbf{C l}$ \\
\hline KSM & 0.132 & 0.06631 & -0.03026 to 0.2943 \\
\hline NS & 0.2714 & 0.0427 & 0.1669 to 0.3759 \\
\hline TJ & 0.193 & 0.0658 & 0.03198 to 0.3540 \\
\hline \multicolumn{2}{|l}{ Note: $\mathrm{Cl}=$ Confidence Interval } \\
\hline
\end{tabular}

Table 2: Significant differences in wound healing between the three groups.

\begin{tabular}{|c|c|l|l|l|l|}
\hline \multicolumn{2}{|c|}{ Variables } & $\begin{array}{l}\text { Mean } \\
\text { difference }\end{array}$ & $\begin{array}{l}\text { Std. Erro } \\
\mathbf{r}\end{array}$ & $\mathbf{P}^{\mathrm{a}}$ & $\mathbf{9 5 \% \mathrm { Cl } ^ { \mathrm { a } }}$ \\
\hline \multirow{2}{*}{$\begin{array}{l}\text { KS } \\
\text { M NS }\end{array}$} & -0.139 & 0.0399 & 0.0387 & -0.271 to -0.00832 \\
\cline { 2 - 6 } & TJ & -0.061 & 0.0206 & 0.0764 & -0.129 to 0.00688 \\
\hline \multirow{2}{*}{ NS } & KSM & 0.139 & 0.0399 & 0.0387 & 0.00832 to 0.271 \\
\cline { 2 - 6 } & TJ & 0.0784 & 0.0499 & 0.5003 & -0.0855 to 0.242 \\
\hline \multirow{2}{*}{ TJ } & KSM & 0.061 & 0.0206 & 0.0764 & -0.00688 to 0.129 \\
\cline { 2 - 6 } & NS & -0.0784 & 0.0499 & 0.5003 & -0.242 to 0.0855 \\
\hline
\end{tabular}

Note: ${ }^{a}=$ Bonferroni corrected; $\mathrm{Cl}=$ Confidence Interval

The study reports that wound healing's acceleration is demonstrated more so by group 1 compared to groups 2 and 3 see Figure 1. The results reveal that group 1 healed faster than did both the control group and group 2 see Table 1. However, the statistical analysis did not report significantly different results between KSM dressing and TJ honey or between $\mathrm{TJ}$ honey and NS, with the exception of KSM dressing and NS, which indeed presented a significant difference, see Table 2. 


\section{Discussion}

In the modern era people are becoming increasingly interested in "natural products" which refer to compounds derived from fruits, plants and herbs. These compounds contain a variety of antioxidants and are both widely available and implemented to treat health problems in the skin. Preclinical research has proven their effectiveness in wound healing as sources of antioxidants and antimicrobials and the use of antioxidant therapy for wound healing is also increasing in demand [20]. Although some of these therapies require a physician's prescription, many alternative wound-healing products are sold inexpensively in the free market. Products for injuries that enter the free market must initially obtain permission to be circulated to account for their safety and efficacy [19]. This study has demonstrated that KSM dressing and TJ honey positively affect wound healing. Dates have exceptional nutritional value, vitamins and mineral deposits that are essential for development and well-being. Dates also possess flavonoid polyphenolate antioxidants that are beneficial to health and are identified as tannins, which are recognized as possessing anti-infectious, anti-inflammatory and anti-hemorrhagic abilities [15]. In Dates large number of antioxidants can play a very important role in the woundhealing process, as antioxidants are important mediators in regulating the damage that may be potentially caused by biological molecules (e.g., DNA, proteins, lipids and body tissues) in the presence of reactive species [21]. Antioxidants are useful in their ability to be relatively unreactive as free radicals and are therefore less likely to spread damage. The contents of dates that have been reported as important minerals for the wound-healing process include $\mathrm{Ca}, \mathrm{Cu}$ and $\mathrm{Zn}$ and these minerals can assist the healing process by providing essential nutrients for wound repair [14]. Dates that contain flavonoids can limit oxidant injury and cell destruction by eliminating oxygen radicals, maintaining lipid oxidative degradation, eliminating radical reactions, activating metal ion transport and forming inactive complexes that cannot cause the radical conversion of superoxide and hydrogen peroxide to hydroxyl radicals [21]. Evaluations of the local work of composites that possess characteristics of free radical elimination in humans have been reported to improve wound healing and defend the process from oxidative injury [22]. In Indonesia, trigona honey is currently widely ingested by the community in oral form to overcome skin health problems (e.g., chronic wounds) and maintain health [12,13]. Trigona honey contains compounds such as flavonoids and tannins. In this study, it has been demonstrated that KSM is a traditional medicinal herb that can be used in wound healing and is likely to be effective due to its content of both flavonoids and tannins, the former of which can promote wound healing through several cellular mechanisms such as by chelating free radicals and reactive oxygen species, accelerating wound contraction and increasing the formation of capillaries and fibroblasts [22]. Whereas flavonoid compounds possess antibacterial properties in their mechanism of action in which these activities disrupt the permeability of bacterial cell walls, microsomes and lysosomes as a result of their interactions with bacterial DNA, flavonoids have been reported to increase collagen synthesis, reduce the degradation of dissolved collagen, encourage collagen crosslinking, accelerate the conversion of dissolved collagen into insoluble collagen and inhibit the catabolism of dissolved collagen. From a clinical point of view, collagen deposition in wounds is the most important healing phase $[20,23]$.

\section{Conclusion}

The current study has revealed that the direct application of KSM in acute wounds may be concluded to significantly improve the wound-healing process in experimental animals. To our knowledge, this study is the first of its kind to demonstrate that KSM can accelerate wound healing. Further studies must evaluate the cellular, biochemical and biological response mechanisms in wound tissue alongside their effects on pathogenic bacteria under chronic wound conditions.

\section{Conflict of Interest}

The author declares no conflict of interest in conducting this study.

\section{References}

1. Dunford C, Cooper R, Molan P, White R (2000) The use of honey in wound management. Nurs Stand 15: 63-68.

2. Haryanto H, Urai T, Mukai K, Suriadi S, Sugama J, et al. (2012) Effectiveness of indonesian honey on the acceleration of cutaneous wound healing: An experimental study in mice. Wounds 24: 110-119.

3. Subrahmanyam M (1991) Topical application of honey in treatment of burns. Br J Surg 78: 497-498.

4. Cooper R, Molan P, Krishnamoorthy L, Harding K (2001) Manuka honey used to heal a recalcitrant surgical wound. Eur J Clin Microbiol Infect Dis 20: 758-759.

5. Molan PC, Smith IM, Reid GM (1988) A comparison of the antibacterial activities of some new zealand honeys. J Apic Res 27: 252-256.

6. Efem SE (1988) Clinical observations on the wound healing properties of honey. Br J Surg 75: 679-681.

7. Suriadi S, Sudirjo W, Ali S, Nurpiyanti A, Kardiatun T, et al. (2018) Case report on the use of a honey on diabetic foot ulcer patients. Int J Indones Natl Nurses Assoc 1: 98-104.

8. Yusop SATW, Asaruddin MR, Sukairi AH, Sabri WMAW (2018) Cytotoxicity and antimicrobial activity of Propolis from Trigona itama stingless bees against Staphylococcus aureus and Escherichia coli. Indones J Pharm Sci Tech 1: 13-20.

9. Bhattacharya M, Wozniak DJ, Stoodley P, Hall-Stoodley L (2015) Prevention and treatment of Staphylococcus aureus biofilms. Expert Rev Anti Infect Ther 13: 1499-1516.

10. Tong SY, Davis JS, Eichenberger E, Holland TL, Fowler VG (2015) Staphylococcus aureus infections: Epidemiology, pathophysiology, clinical manifestations and management. Clin Microbiol Rev 28: 603-661.

11. Crosby HA, Kwiecinski J, Horswill AR (2016) Staphylococcus aureus aggregation and coagulation mechanisms, and their 
function in host-pathogen interactions. Adv Appl Microbiol 96: 1-41.

12. Kurniawati D (2011) Uji Aktivitas Antibakteri Propolis Trigona spp. Asal Bukit Tinggi Pada Tikus Putih Sprague-Dawle. J prog kim si 1: 25-31.

13. Saleng A, Syafrizal S, Sari YP (2016) Uji aktivitas antibacter ekstrak propolis lebah Trigona incisa terhadap bakteri klebsiella pneumonia dan Staphylococcus aureus. J Ilmiah Biologi 11: 42-48.

14. Abdennabi R, Bardaa S, Mehdi M, Rateb ME, Raab A, et al. (2016) Phoenix dactylifera L. sap enhances wound healing in Wistar rats: Phytochemical and histological assessment. Int J Biol Macromol 88: 443-450.

15. Elgohary H, Jaouni SA, Selim S (2017) Wound healing: In response to natural remedies and phototherapy. Int J Res Pharm Sci 8: 568-575

16. Hasson SS, Al-Shaqsi MS, Albusaidi JZ, Al-Balushi MS, Hakkim FL, et al. (2018) Influence of different cultivars of Phoenix dactylifera L-date fruits on blood clotting and wound healing. Asian Pac J Trop Biomed 8: 371-376.

17. Javed A, Usman M, Haider SM, Zafar B, Iftikhar K, et al. (2019) Potential of indigenous plants for skin healing and care. American Scient Res J Engi Tech Sci 51: 192-211.
18. Abdennabi R, Othmani A, Triki MA, ELGheryeni A, Gharsallah N (2018) Development of a date palm (Phoenix dactylifera L.) sap based economical cost effective media suitable for in vitro growth of date palm and microbial culture. EC Agri 13: 3-16.

19. Dorai AA (2012) Wound care with traditional, complementary and alternative medicine. Indian J Plast Surg 45: 418-424.

20. Fitzmaurice SD, Sivamani RK, Isseroff RR (2011) Antioxidant therapies for wound healing: A clinical guide to currently commercially available products. Skin Pharmacol Physiol 24: $113-126$.

21. Canales-Aguirre A, Carvallo-Aceves A, Manzano-Chavez L, Padilla-Camberos E, Lugo-Cervantes E, et al. (2008) Wound healing and antioxidant activities of extracts from Musa paradisiaca L. peel. Planta Med 74: 1-9.

22. Pawar RS, Toppo FA (2012) Plants that heal wounds. A review. Herba Polon 58: 47-65.

23. Lodhi S, Singhai AK (2013) Wound healing effect of flavonoid rich fraction and luteolin isolated from Martynia annua Linn. on streptozotocin induced diabetic rats. Asian Pac J Trop Med 6: 253-259. 